The clinical picture could equally well be explained by other intramedullary lesions-for example, glioma or ependymoma and other cystic lesions of the cord. It is clearly important to be able to distinguish between these clinical possibilities so as to plan rational therapy, particularly for the cystic intramedullary tumours. Radiological studies can help to elucidate the nature of the intramedullary lesion. Plain radiographs of the cervical spine may show an abnormally wide canal. ${ }^{1}$ But it is with the advent of contrast radiological techniques, myelography, and more recently gas myelography, ${ }^{23}$ that cystic lesions of the cervical part of the spinal cord have been detected and contrasted with the more typical collapsed intramedullary cyst of syringomyelia.

In a comprehensive study A. B. Ellertsson ${ }^{45}$ reviews the whole problem of syringomyelia and cystic lesions of the spinal cord. The detailed case histories of 34 cases of syringomyelia were studied. They all showed dissociated sensory loss, insidious onset, slow progression, and a total protein content in the cerebrospinal fluid of less than $70 \mathrm{mg}$. per $100 \mathrm{ml}$. In 30 of the cases it was possible to show, by gas myelography and tilting the examination table so as to view the cervical canal at different angles, that they had an elongated, flaccid cyst of the spinal cord. The remaining four patients probably had syringomyelia but without the radiological evidence of a collapsed cyst. As well as the usual features all the patients with syringomyelia had their first symptom before the age of 40 . That syringomyelia may be present in association with skeletal and vascular abnormalities in the foramen magnum region, ${ }^{6}$ or at least the clinical features of syringomyelia, ${ }^{7-9}$ is well recognized. But in Ellertsson's series, of the two cases of Arnold-Chiari deformity one showed a normal myelographic appearance and the other an atrophic spinal cord.

Ellertsson ${ }^{5}$ also reviewed the clinical picture in 29 patients with an intramedullary non-fluctuating or partially fluctuating lesion of the spinal cord due to a distended cyst. The lesion was situated in the cervical region in seven and in the cervico-thoracic region in another seven. The majority were associated with a spinal glioma. Unlike the picture in syringomyelia, the combination of dissociated sensory loss with muscular atrophy in the arms and a low protein content of the cerebrospinal fluid was uncommon. In particular the protein in the cerebrospinal fluid was above $70 \mathrm{mg}$. per $100 \mathrm{ml}$. in 23 of these 29 cases and above $100 \mathrm{mg}$. per 100 $\mathrm{ml}$. in 17. Another point of difference between syringomyelic cavitation and other intramedullary cysts is that percutaneous puncture of the cyst or cavity did not affect the clinical course of the disease in nine patients with syringomyelia, but did benefit five out of six patients with other cystic lesions.

The aetiology of syringomyelia remains obscure. Though a history of trauma may be forthcoming, it is not the rule.

1 Spillane, J. D., Pallis, C., and Jones, A. M., Brain, 1957, 80, 11.

2 Conway, L. W., Transactions of the American Neurological Association, 1961, 86, 205.

- Westberg, G., Acta Radiologica. Diagnosis Supplement, 1966, 252, 67.

- Ellertsson, A. B., Acta Neurologica Scandinavica, 1969, 45, 385.

- Ellertsson, A. B., Acta Neurologica Scandinavica, 1969, 45, 403.

- Gardner, W. J., and Goodall, R. J., foumal of Neurosurgery, 1950, 7, 199.

? Symonds, C. P., and Meadows, S. P., Brain, 1937, 60, 52.

- Lavy, S., Eyal, Z., and Schwartz, A., Acta Neurochirurgica, 1960, 8, 532.

- Bharucha, E. P., and Dastur, H. M., Brain, 1964, 87, 469.
A congenital lesion with cavitation or with abnormal glial tissue in the centre of the cord is the most widely held explanation, but definite evidence for it is lacking except in those cases which are associated with other congenital malformation of the cervical spine.

\section{Family Planning Services}

Relatively few local authorities have set up full family planning services since they were granted the right to do this

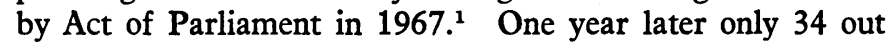
of the 204 local health authorities in England and Wales were providing a full service. ${ }^{2}$ Undoubtedly, however, there is a great demand for advice in this field, as the experience of the Family Planning Association has shown. Between 1966 and 1969 the number of F.P.A. clinics in operation rose from 613 to 935 , while the number of doctor-sessions almost doubled, now totalling over 100,000 every year. $^{34}$

With the F.P.A. playing such an important part in this programme many of its friends will regret the current controversies going on within it, which led finally to the resignation of its medical director, Dr. Hilary Hill, earlier this month. In a statement to an unofficial meeting of F.P.A. clinic doctors on December 15 Dr. Hill spoke of the considerable authority vested in her in the past. More recently, however, she had been conscious of a "progressive erosion" of her professional authority, which made it impossible for her to continue to work effectively. She feared that present trends might lead to a less professional service and that the relationship betwen the clinic doctor and the patient might be endangered.

Though fitting contraceptive devices or prescribing the right pill requires considerable training and experience, there is much more to a proper family planning service. The patient may need to discuss her psychosexual problems or other medical matters related to her contraceptive needs. The clinic doctor may decide that a full medical examination is indicated, or that, for example, a cervical smear test should be done. Indeed, apart from family limitation and the spacing of children, the Objects of the F.P.A. ${ }^{4}$ speak of medical advice and treatment for involuntary sterility and failure to conceive; difficulties connected with the marriage relationship; and the taking of gynaecological and genitourinary specimens for diagnostic purposes. Such a comprehensive service can be provided only by a properly trained, medically qualified person given enough time to talk to each patient and assess her needs. It is to be hoped that the committee of inquiry, which has been set up by the F.P.A. under the chairmanship of Lord Platt to examine the association's medical structure and function, will recognize the value of a sympathetic, unhurried approach to a subject which many patients still find embarrassing.

\footnotetext{
1 British Medical fournal, 1967, 2, 385.

2 British Medical fournal, 1969, 3, 64.

s Hill, H., British Medical fournal, 1969, 3, 477.

- Family Planning Association 37th Annual Report and Accounts, 1967-8, 1968. London, F.P.A.
} 